\title{
Sosialisasi Pengolahan Limbah Medis Di RSUD Gambiran Kota Kediri
}

\author{
Yuly Peristiowati ${ }^{1}$, A. Sani Fajriah ${ }^{2,}$ Norina Listya Irmala ${ }^{3}$ \\ ${ }^{1}$ Jurusan Keperawatan, Institut Ilmu Kesehatan STRADA, Kediri \\ ${ }^{2}$ Jurusan Kebidanan, Institut Ilmu Kesehatan STRADA, Kediri \\ ${ }^{3}$ Jurusan Kesehatan Masyarakat, Institut Ilmu Kesehatan STRADA, Kediri \\ Email : yulystikes@gmail.com
}

\begin{abstract}
Background: Waste products from a medical activity that must be processed immediately after being produced can be referred to as Medical Waste. Improper processing of medical waste will increase the source of infection and can lead to the risk of nosocomial infection. Data from the sanitarian section of Gambiran Kediri Hospital said that in 1 day on average $190 \mathrm{~kg}$ of medical waste was produced, including injection equipment, ampoules, infusion bottles, infusion hoses, catheters, used injection bottles, gloves, masks, cotton wool, plaster, and medicine packs., gauze and bandages, produced by 20 wards. This activity aims to carry out the socialization of Medical Waste Treatment at Gambiran Hospital, Kediri City. Methods: The method used is in the form of counseling on how to process Medical Waste starting from the initial disposal site in the room to the TPS B3 section (B3 Waste Disposal Place with the leaflet method, and electronic media in the hospital. Results: The results of this community service activity are: It was found that problems related to the processing of medical waste were still mixed with medical waste and non-mediated waste in several rooms, the color of the plastic bags used did not match the SOP, the time used to distribute clean linen was not in accordance with the SOP.Conclusion: After community service was carried out in RSUD Gambiran Kediri City, we have various problems including gaps between targets and achievements. By using the data we have obtained, we process the data by determining priority problems based on USG (Usgensi Seriousness Growth), based on the results of the analysis of priority problems we determine the SWOT analysis, determine intervention and then carry out the implementation according to the problems that are found to be appropriate.
\end{abstract}

Keyword: medical waste, processing, socialization

\section{PENDAHULUAN}

Usaha yang di lakukan dalam rangka meningkatkan kesehatan dan mencegah penyakit merupakan salah satu dari tujuan Sanitasi Lingkungan. Pengelolaan lingkungan Rumah Sakit merupakan bagian penting dari rangkaian siklus dan strategi manajemen Rumah Sakit untuk mengembangkan kapasitas pengelolaan lingkungan Rumah Sakit dalam memberikan pelayanan baik secara tidak langsung terhadap peningkatan kualitas pelayanan Rumah Sakit secara menyeluruh(Purwanti, 2015).

Salah satu dampak keberadaan Rumah Sakit adalah terjadinya pencemaran lingkungan dan adanya sumber penularan penyakit. untuk mengatasi dampak negatif keberadaan rumah sakit tersebut perlu adanya pengawasan yang maksimal terkait sanitasi rumah sakit meliputi kebersihan gedung kamar mandi/WC, kebersihan halaman dan limbah. yang mencakup faktor lingkungan fisik, kimiawi dan biologi yang mengakibatkan gangguan kesehatan pada petugas, pasien, pengunjung maupun bagi masyarakat di sekitar rumah sakit(Pratiwi \& Maharani, 2013).

Pengelolaan rumha sakit yang kurang baik dapat merupakan sumber infeksi nosokomial dan pencemaran lingkungan yang berdampak pada kesehatan pasien, 

pengunjung, petugas kesehatan, masyarakat sekitar. Pengelolaan kesehatan lingkungan Rummah Sakit mengacu pada Keputusan Menteri Kesehatan RI Nomor 1204/MENKES/SK/X/2004 tentang Persyaratan Kesehatan Lingkungan Rumah Sakit sebagai pendukung usaha penyembuhan penderita disamping mencegah terjadinya penularan infeksi nosokomial kepada orang sehat baik petugas rumah sakit, pengunjung maupun masyarakat di sekitar rumah sakit. Saat ini, sudah berlaku peraturan baru terkait kesehatan Lingkungan Rumh Sakit dalam Peraturan Menteri Kesehatan R.I. No. 7 Tahun 2019(Mentri Kesehatan Republik Indonesia, 2019).

Dalam pengelolaan sarana pelayanan kesehatan, di butuhkan suatu program penataan oleh pemerintah daerah dalam bentuk penegakkan hukum. Pengawasan dan pemantauan sarana pelayanan kesehatan, merupakan salah satu cara untuk mengetahui apakah pengelola sarana kesehatan tersebut mentaati ketentuan perundang undangan lingkungan hidup dan persyaratan baku mutu dan ambang batas. Pengawasan dan pemantauan yang di lakukan secara terpadu dan rutin akan dapat meningkatkan kemampuan pengelola sarana kesehatan untuk mentaati ketentuan dan jika ada yang melanggar ketentuan akan mendapatkan sanksi(Maulana, Kusnanto, \& Agus, 2017).

Dari hasil pengkajian awal di bagian Sanitarian RSUD Gambiran Kota Kediri di dapatkan data timbulan limbah medis rata-rata $190 \mathrm{~kg}$ per hari. Limbah medis tersebut berasal dari ruangan yang menghasilakan limbah medis yaitu ruang rawat inap dan rawat jalan sebanyak 20 ruangan. Karakteristik limbah medis tersebut adalah alat injeksi, ampul, botol infus, selang infus, kateter, botol bekas obat injeksi, sarung tangan, masker, kapas, plester,bungkus obat, kasa, perban.

Dari hasil observasi, di setiap ruangan telah dilakukan pewadahan limbah medis sesuai dengan jenisnya. Pewadahan limbah medis padat berbahan dari plastik, kedap air, dilapisi dengan kantong plastik kuning dan tertutup. Peletakkan wadah limbah medis padat di setiap ruang di letakkan di sepanjang jalan koridor ruangan. Dari 14 ruang rawat inap terdapat 5 ruangan yaitu ruang kertajaya, sekartaji, galuh, pamenang dan jenggala limbah medis nya tercampur dengan limbah non medis. Proses pengolahan limbah medis mulai dari timbulan hingga pengelolaan akhir $75 \%$ cukup baik. Selain itu petugas medis maupun non medis terdapat $47 \%$ belum mengikuti pelatihan pengolahan limbah (data diklat RSUD Gambiran Kota Kediri., 2019).

Dari Latar Belakang di atas, tujuan pengabdian masyarakat yang akan di lakukan adalah melalukan sosialisasi kepada semua karyawan, pasien dan keluarga pasien di RSUD Gambiran Kota Kediri terkait pengolahan limbah medis mulai dari tempat pembuangan awal sampai pada TPS B3.

\section{TINJAUAN PUSTAKA}

\subsection{Limbah Padat}

a. Pengertian Limbah

Limbah padat dapat diartikan sebagai bahan hasil buangan yang sudah tidak berguna yang berbentuk padat yang meliputi garbage, rubbish, ashes dan bangkai binatang. 
Adapun sampah yang mudah membusuk dan bersal dari penyiapan pengolahan dan penyajian makanan disebut Garbage. Sedangkan sampah yang mudah membusuk di sebut Rubbish. Sampah yang dihasilkan dari diagnose dan tindakan medis terhadap pasien, termasuk bahan-bahan medis pembedahan, otopsi, dan laboratorium di sebut sebagai sampah biologi. Limbah medis dapat dihasilkan d, ruang pengori ruang perawatan, ruang pembedahan termasuk dreesing kotor, veban, kateter, swab, plater, masker dan lain-lain. Sedangkan limbah patologis dapat di hasilkan dari ruang bedah atau ruang autopsy, diantaranya placenta, jaringan, organ dan anggota badan . Sampah yang dihasilkan dari laboratorium diagnostic atau riset, meliputi sediaan atau media sampel spinal, bangkai binatang di sebut Limbah laboratorium.(Yani, Dharma, \& Nurmaini, 2015).

\subsection{Sumber Limbah Padat}

Limbah padat dapat rumah sakit, kantor atau administrasi yang berupa limbah non medis seperti kertas, plastic dan lainnya. Sedangkan limbah padat yang tergolong limbah medis bersumber dari unit obstetric dan ruang perawatan obstetric seperti dressing, sponge, placenta, ampul, termasuk kapsul perak nitrat, jarum syringe, masker disposable, disposable drapes, sanitary napkin, blood lancet disposable, disposable catheter, disposable unit enema, disposable diaper dan underpad, sarung tangan disposable. Limbah medis lainnya bersumber dari unit emergency dan bedah yang berupa dressing, sponge, jaringan tubuh, termasuk amputasi, ampul bekas, masker disposabale, jarum dan syringe drapes, casb, disposable blood lancet, disposable kantong emesis, Levin tubes, chateter, drainase set, kantong colosiomy, underpads, sarung bedah. Unit lain yang dapat menjadi sumber limbah medis adalah unit laboratorium, ruang mayat, pathologi dan autopsy Adapun unit yang menghasilkan limbah padat non medis meliputi unit pelayanan, unit gizi dengan limbah seperti karton, kertas bungkus, kaleng, botol, sisa makanan, sisa pembungkus, sisa bahan makanan, sayur dan lain-lain(Masyarakat, 2018).

\subsection{Jenis dan karakteristik limbah}

Berdasarkan jenisnya Limbah Rumah Sakit dapat digolongkan menjadi limbah medis dan non medis. Sedangkangkan menurut karakteristiknya limbah rumah sakit di golongkan menjadi 4 sampah yaitu :

a. Sampah infeksius : merupakan sampah yang berasal dari pasien yang diisolasi, pemeriksaan mikrobiologi, poliklinik, perawatan, penyakit menular yang dapat menjadi sumber penularan penyakit.

b. Sampah sitotoksik merupakan bahan yang terkontaminasi radioisotope

c. Sampah domestik merupakan sampah yangberasal dari dengan tindakan pelayanan terhadap pasien.

d. Jenis sampah non-medis atau sampah domestik dimasukkan kedalam tempat sampah khusus yaitu kantong keresek warna hitam(Purwanti, 2015) . 


\subsection{Penyelenggaraan pengamanan limbah}

Penyelenggaraan Pengamanan Limbah di rumah sakit meliputi pengamanan terhadap limbah padat non medis, limbah bahan berbahaya dan beracun (B3), limbah cair, dan limbah gas (Maulana et al., 2017).

\section{a. Penyelenggaraan pengamanan limbah padat non medis}

Pengamanan limbah padat non medis merupakan upaya penanganan limbah padat non medis di rumah sakit yang memenuhi standar untuk mengurangi risiko gangguan kesehatan, kenyamanan dan keindahan yang ditimbulkan. Untuk menjamin pengelolaan limbah padat domestik dapat dilaksanakan sesuai dengan tahapan penyelenggaraan yaitu : Pemilihan, Pewadahan , Pengangkutan dan penyimpakan di TPS (Masyarakat, 2018).

\section{b. Penyelenggaraan pengamanan limbah padat medis}

Prinsip pengelolaan limbah B3 rumah sakit, dilakukan upaya sebagai berikut yaitu mengidentifikasi jenis limbah B3, penanganan pewadahan dan pengangkutan limbah B3diruangan sumber (Purwanti, 2015).

\subsection{Pengolahan Limbah B3 di rumah sakit}

Pengolahan limbah B3 di rumah sakit dapat dilaksanakan secar internal dan eksternal. Pengolahan secara internal dilakukan di lingkungan rumah saki dengan menggunakan alat insinerator atau alat pengolah limba B3 lainnya yang disediakan sendiri oleh pihak rumah sakit (on-site) seperti autoclave, microwave, penguburan, enkapsulasi, inertisias yang mendapatkan izin operasional dan dilaksanakan sesuai denga ketentuan peraturan perundang-undangan. Pengolahan secara eksternal dilakukan melalui kerja sama dengan pihak pengolah atau penimbun limbah B3 yang telah memiliki ijin. Pengolahan limbah B3 secara internal dan eksternal dilaksanakan sesuai dengan ketentuan peraturan perundang-undangan. Rumah sakit yang melakukan pengolahan limbah B3 secar internal dengan insinerator, harus memiliki spesifikasi pengolah yang sesuai dengan ketentuan peraturan perundang- undangan (Mentri Kesehatan Republik Indonesia, 2019; Purwanti, 2015).

\section{DESAIN PENELITIAN}

Kegiatan pengabdian masyarakat ini dilakukan melalui beberapa tahapan kegiatan yaitu :

a. Survey awal

Survey dilakukan terhadap aktivitas pembuangan dan pengolahan sampah medis pada masing-masing ruangan di RSUD Gambiran Kediri. Kegiatan ini dilakukan pada tanggal 12 sd 15 Oktober 2020. Metode yang dipakai adalah metode observasi dan wawancara dengan sasaran kegiatan adalah karyawan terutama cleaning Servis, Perawat, Bidan dan petugas kesehatan lain serta pasien.

b. Pelaksanaan Kegiatan

Kegiatan ini dilakukan pada tanggal 18 Oktober 2020 sd 25 Oktober 2020. Pelaksanaan kegiatan pengabdian masyarakat ini diwujudkan dalam kegiatan sosialisasi terkait pengolahan sampah medis pada karyawan dan pasien di RSUG Gambiran Kota Kediri . 
c. Evaluasi

Setelah dilakukan pengabdian masyarakat di RSUD Gambiran Kota Kediri, kami mendapatkan berbagai masalah diantaranya terdapat kesenjangan antar target dan capaian. Dengan menggunakan data yang telah kami peroleh, kami mengolah data tersebut dengan menentukan prioritas masalah berdasarkan USG (Usgensi Seriousness Growth), berdasarkan hasil analisis prioritas masalah kami menentukan Analisis SWOT, menetukan intervensi dan kemudian melakukan implementasi sesuai dngan masyalah yang ditemukan dengan tepat, dan setelah di lakukan Implementasi dengan melakukan sosialisasi dan penyuluhan sudah berkurang jumlah sampah medis dan non medis yang bercampur.

\section{HASIL PENELITIAN}

\section{a. Data Pengkajian}

Pengolahan Limbah Medis

Timbulan yang dihasilkan limbah medis rata-rata $190 \mathrm{~kg}$ per hari (catatan dari sanitarian). Limbah medis tersebut dihasilkan dari ruangan yang menghasilakan limbah medis yaitu ruang rawat inap dan rawat jalan sebanyak 20 ruangan. Karakteristik limbah medis tersebut adalah alat injeksi, ampul, botol infus, selang infus, kateter, botol bekas obat injeksi, sarung tangan, masker, kapas, plester, bungkus obat, kasa, perban.

Dari hasil observasi yang telah dilakaukan pewadahan telah tersedia disetiap ruang kegiatan pelayanan kesehatan. Pewadahan limbah medis telah disediakan sesuai dengan jenisnya. Pewadahan limbah medis padat berbahan dari plastik, kedap air, dilapisi dengan kantong plastik kuning dan tertutup. Peletakkan wadah limbah medis padat di setiap ruang di letakkan di sepanjang jalan koridor ruangan. Dari 14 ruang rawat inap terdapat 5 ruangan yaitu ruang kertajaya, sekartaji, galuh, pamenang dan jenggala limbah medis nya tercampur dengan limbah non medis. Proses pengolahan limbah medis mulai dari timbulan hingga pengelolaan akhir $75 \%$ cukup baik. Selain itu petugas medis maupun non medis terdapat $47 \%$ belum mengikuti pelatihan pengolahan limbah (data diklat 2019).

Hasil Analisa SWOT Pengolahan Limbah Medis :

\begin{tabular}{|c|c|}
\hline $\begin{array}{l}\quad \text { Kekuatan (Strenght) } \\
\text { 1. RSUD Gambiran memiliki SOP } \\
\text { lengkap tentang pengelolaan } \\
\text { limbah Medis } \\
\text { 2. Petugas sanitasi secara rutin } \\
\text { melakukan pengawasan di setiap } \\
\text { ruangan } \\
\text { 3. Di setiap ruangan tersedia wadah } \\
\text { dan di bedakan menurut jenis } \\
\text { limbah } \\
\text { 4. Fasilitas untuk pengolahan limban } \\
\text { medis sudah tersedia }\end{array}$ & $\begin{array}{l}\text { Kelemahan (Weaknesses) } \\
\text { 1. Ruang kertajaya, sekartaji, galuh, } \\
\text { pemenang dan jenggala, limbah } \\
\text { medis tercampur dengan limbah } \\
\text { nonmedis } \\
\text { 2. } 47 \% \text { petugas medis dan nonmedis } \\
\text { belum pelatihan pengolahan limbah } \\
\text { 3. SOP tentang pengelolaan limbah } \\
\text { medis Covid-19 masih dalam } \\
\text { proses }\end{array}$ \\
\hline
\end{tabular}




\begin{tabular}{|c|c|}
\hline $\begin{array}{l}\text { Peluang (Opportunities) } \\
\text { 1. Kerjasama dengan pihak ke III } \\
\text { untuk mengolahan tahap akhir } \\
\text { limbah medis } \\
\text { 2. Adanta program pelatihan kepada } \\
\text { petugas pengelolaan limbah medis } \\
\text { untuk refresh ilmu }\end{array}$ & \begin{tabular}{l}
\multicolumn{1}{c}{ Ancaman (Treats) } \\
1. Pengangkutan limbah medis dari \\
pihak ke III tidak mencukupi \\
jumlah limbah medis yang di \\
hasilkan \\
2. Kurangnya pengetahuan pasien \\
dan keluarga tentang membedakan \\
jenis limbah medis
\end{tabular} \\
\hline
\end{tabular}

Table 1. Hasil Analisis SWOT Masalah Pengolahan Limbah Medis

Kegiatan Pengabdian Masyarakat ini merupakan tindaklanjut dari kegiatan Residensi yang dilaksanakan di RSUD Gambiran Kota Kediri. Pada Kegitan Residensi di temukan beberapa permasalahan terkait pengolahan sampah medis yaitu :

1. Ruang kertajaya, sekartaji, galuh, pamenang dan jenggala limbah medis tercampur dengan limbah non medis

2. $47 \%$ petugas medis dan non medis belum berpelatihan pengolahan limbah

3. SOP tentang pengelolaan limbah medis covid-19 masih dalam proses, sudah di susun, sudah di revisi, dan masih di jajaran manajemen Rumah Sakit.

\section{Rencana Intervensi}

1. Ruang kertajaya, sekartaji, galuh, pamenang dan jenggala limbah medis tercampur dengan limbah non medis dilakukan :

Penyuluhan dan sosialisi tentang limbah medis kepada petugas medis, non medis dan pasien di ruangan yang bersangkutan

2. Memberikan reward apabila pemilihan limbah medis sudah tidak ada yang tercampur dengan limbah non medis

3. Penyusunan SOP tentang pengelolaan limbah medis covid-19

\section{Implementasi}

1. Penyuluhan dan sosialisai tentang limbah medis kepada petugas medis, non medis dan pasien di Ruang kertajaya, sekartaji, galuh, pamenang dan jenggala dilaksanakan selama 1 minggu yaitu mulai tanggal 18 Oktober 2020 sd 25 Oktober 2020

2. Pemberian reward kepada karyawan dan pasien yang memilah pembuangan sampah medis dan non medis masih di lakukan pujian dan ucapan terimakasih. sedangkan reward berupa souvenir belum bisa terealisasi.

3. Penyusunan SOP tentang pengelolaan limbah medis covid-19 masih dalam proses, sudah dilakukan revisi dan masih di analisa di bagian manajemen. 


\section{PEMBAHASAN}

Dari hasil pengkajian data awal, proses pengolahan limbah medis di RSUD Gambiran Kota Kediri sudah berjalan dengan baik meskipun pada waktu pengumpulan limbah medis pada tempat sampah medis masih ada sebagian bercampur dengan limbah non medis. Limbah medis berasal dari 20 ruang perawatan inap dan rawat jalan yang meliputi limbah medis berasal dari alat injeksi, ampul, botol infus, selang infus, kateter, botol bekas obat injeksi, sarung tangan, masker, kapas, plester, bungkus obat, kasa, perban. Dalam 1 hari terdapat $190 \mathrm{~kg}$ limbah padat medis yang selanjutnya di masukkan dalam kantong plastik, kedap air, dilapisi dengan kantong plastik kuning dan tertutup. Peletakkan wadah limbah medis padat di setiap ruang di letakkan di sepanjang jalan koridor. Selanjutnya Limbah medis tersebut di kumpulkan dalam Tempat Pembuangan Sampah (TPS) B3, sebagai tempat penampungan sementara dari limbah medis padat tersebut. Selanjutnya limbah padat medis tersebut akan dilakukan pengolahan oleh pihak ke 3 yaitu perusahaan yang memenuhi persyaratan dalam pengolahan limbah medis (B3 ), Bahan Beracun, dan Berbahaya.

Di Rumah Sakit Umum Gambiran kota Kediri, pengolahan limbah cair di lakukan secara mandiri oleh rumah sakit di bawah program kerja Instalasi Penyehatan Lingkungan (IPL). Sedangkan tindak lanjut pengolahan limbah dan sebagai tempat uji air limbah sebagai bentuk implementasi dalam penerapan peraturan tentang baku mutu air limbah rumah sakit dilakukan oleh pihak eksternal. Pengelolaan Limbah Bahan Berbahaya dan Beracun telah dilakukan Rumah Sakit Umum Daerah Gambiran Kediri, dengan melalukan pengangkutan sampah-sampah medis non medis, pembuatan TPS limbah B3, sampai dengan proses pengolahan limbah B3 yang dilakukan oleh pihak ketiga yang bekerja sama dengan Rumah Sakit Umum Daerah Gambiran Kediri, yaitu PT PRIYA Mojokerto.

Proses pengelolaan Limbah Medis di RSUD Gambiran Kota Kediri sudah sesuai dengan Peraturan Menteri Kesehatan R.I. No. 7 Tahun 2019 tentang persyaratan kesehatan lingkungan Rumah Sakit. Secara umum, proses pelaksanaan pengolahan limbah di Rumah Sakit Umum Daerah Gambiran Kediri sudah berjalan dengan baik. Hal ini ditunjukkan dengan hasil akhir yang telah sesuai standar peraturan yang dijadikan acuan dalam pengolahan. Akan tetapi, masih ada beberapa hal yang menjadi kendala dan hambatan dalam pelaksanaan pengolahan seharihari, yaitu diantaranya :

1. Sarana dan prasarana untuk pengolahan limbah mengalami kerusakan sehingga tidak maksimal di gunakan.

2. Lahan untuk pengolahan sampah kurang memadahi, sehingga masih banyak sampah yang bertumpuk.

3. Pengetahuan masyarakat terutama pasien dan keluarga pasien tentang pemilahan limbah medis dan non medis masih rendah sehingga massih ada beberapa ruangan yang limbahnya tercampur.

Dari hasil analisa SWOT di dapatkan Kekuatan (strenght) yang dimliki oleh RSUD Gambiran adalah : RSUD Gambiran telah memiliki SOP lengkap tentang pengolahan limbah medis, petugas sanitasi secara rutin melakukan pengawasan disetiap ruangan, Pada setiap ruangan sudah di sediakan tempat sampah atau wadah yang sudah di bedakan menutut jenis limbah, Fasilitas untuk pengolahan limbah medis cair sudah 
tersedia dan untuk limbah padat kerjasama dengan pihak ke tiga. Adapun Kelemahan (weaknesses) yang saat ini ada adalah ada beberapa ruangan yang masih tercampur antara limbah medis dan non medis dalam satu wadah, $47 \%$ petugas medis dan non medis belum berpelatihan pengolahan limbah dan SOP tentang pengelolaan limbah medis covid-19 masih dalam proses. Sedangkan Peluang (opportunities) yang dimiliki RSUG Gambiran saat ini adalah adanya kerjasama dengan pihak ke III untuk pengolahan tahap akhir limbah medis dan adanya program pelatihan kepada petugas pengelolaan limbah medis untuk merefresh ilmu secara maintanace. Sedangkan Ancaman (threats) yang saat ini di miliki adalah Pengangkutan limbah medis dari pihak ke III tidak mencakupi jumlah limbah medis yang dihasilkan, sehingga masih terdapat sisa limbah medis yang belum bisa terangkut. Selain itu juga Kurangnya pengetahuan pasien dan penunggu pasien tentang membedakan jenis limbah medis. Setelah dilakukan implementasi dalam kegiatan Pengabdian kepada Masyarakat ini, yaitu dilakukan penyuluhan dan sosialisasi kepada karyawan dan pasien beserta keluarga banyak terjadi perubahan terutama dalam pemilihan limbah untuk di buang ke tempat sampah yang telah disediakan sesuai dengan jenis limbah. Sudah semakin berkurang tercampurnya limbah medis dan non medis dalam satu wadah tong sampah, sehingga dapat mempermudah proses pengolahan selanjutnya.

\section{KESIMPULAN DAN SARAN}

\section{a. Kesimpulan}

Setelah dilakukan pengabdian masyarakat di RSUD Gambiran Kota Kediri, kami mendapatkan berbagai masalah diantaranya terdapat kesenjangan antar target dan capaian. Dengan menggunakan data yang telah kami peroleh, kami mengolah data tersebut dengan menentukan prioritas masalah berdasarkan USG (Usgensi Seriousness Growth), berdasarkan hasil analisis prioritas masalah kami menentukan Analisis SWOT, menetukan intervensi dan kemudian melakukan implementasi sesuai dngan masalah yang ditemukan dengan tepat dan menjadi solusi pemecahan dengan melakukan sosialisasi dan penyuluhan kepada karyawan, dan pasien serta keluarga pasien tentang pengolahan limbah medis.

b. Saran

Meningkatkan pengawasan terhadap sanitasi lingkugan rumah sakit sesuai dengan standart yang telah ditetapkan, agar kualitas nilai sanitasi lingkungan rumah sakit lebih baik.

\section{UCAPAN TERIMA KASIH}

Penghargaan setinggi-tingginya untuk RSUD Gambiran Kota Kediri, bagian IPL (Instalasi Penyehatan Lingkungan) RSUD Gambiran Kota Kediri, Institut Ilmu Kesehatan STRADA Indonesia yang telah mensupport penuh kegiatan ini sehingga kegiatan pengabdian masyarakat ini bisa terlaksana dengan baik. 


\section{DAFTAR RUJUKAN}

Kementerian Kesehatan Republik Indonesia. (2019). Peraturan Mentri Kesehatan Republik Indonesia Nomer 7 Tahun 2019 tentang Kesehatan Lingkungan Rumah Sakit (Vol. 8).

Masyarakat, J. K. (2018). Evaluasi Pengelolaan Limbah Medis Padat Bahan Berbahaya Dan Beracun (B3) Di Rumah Sakit Tk. Ii 04.05.01 Dr. Soedjono Magelang. Jurnal Kesehatan Masyarakat (e-Journal), 6(4), 485-495.

Maulana, M., Kusnanto, H., \& Agus, S. (2017). Pengolahan Limbah Padat Medis Dan Pengolahan Limbah Bahan Berbahaya Dan Beracun Di Rs Swasta Kota Jogja. The 5th Urecol Proceeding, 2 (1)(February), 184-190. Retrieved from http://lpp.uad.ac.id/wp-content/uploads/2017/05/24.-muchsin-184-190.pdf

Pratiwi, D., \& Maharani, C. (2013). Pengelolaan Limbah Medis Padat Pada Puskesmas Kabupaten Pati. KESMAS - Jurnal Kesehatan Masyarakat, 9(1), 7484. https://doi.org/10.15294/kemas.v9i1.2833

Purwanti, A. A. (2015). Pengelolaan Limbah Padat Bahan Berbahaya Dan Beracun (B3) Rumah Sakit Di RSUD Dr.Soetomo Surabaya. Departemen Kesehatan Lingkungan Fakultas Kesehatan Masyarakat Universitas Airlangga.

Yani, P., Dharma, S., \& Nurmaini. (2015). Sistem Pengelolaan Limbah Medis Padat Dan Cair Serta Faktor-Faktor Yang Berkaitan Dengan Pelaksanaan Pengelolaan Limbah Medis Padat Dan Cair Di Rumah Sakit Umum Kabanjahe Kabupaten Karo TAHUN 2015. Universitas Sumatera Utara. 